\title{
水棲生物の遊泳行動追跡用スマートポップアップタグの開発

\author{
Development of Smart Pop-up Tag \\ for Swimming Behavior Logging of the Aquatic Organisms
}

\author{
天野 亮*・谷本浩 - * ・ 中山敬三*・越智洋司*・前田佳 伸* \\ Ryo AMANO, Hirokazu TANIMOTO, Keizo NAKAYAMA, Youji OCHI and Yoshinobu MAEDA
}

\author{
(Received March 28. 2016)
}

\begin{abstract}
Ecological studies of the aquatic organisms using data loggers have been carried out in order to research a resources state of the aquatic organisms. One of data loggers to be used in the studies is an archival pop-up tag. Archival pop-up tags widely used have an ARGOS transmitter for facilitating recovery of tags. On the other hand, they have few sensors such as an illuminometer, a pressure sensor and a temperature sensor by the reason of a small-capacity battery and small buoyancy. Therefore it is difficult to know finescale movements of aquatic organisms from data collected by typical pop-up tags with an ARGOS transmitter. We have developed a smart pop-up tag which has a 3-axis accelerometer and a 3-axis angular velocity sensor in addition to an illuminometer, a pressure sensor and a temperature sensor. This tag allows us to obtain fine-scale movements of target animals. This tag also has an ARGOS transmitter which is driven by a solar cell. We have verified that the tag works properly in a pretest.
\end{abstract}

Key Words: Pop-up Tag, Accelerometer, Angular Velocity Sensor, Solar Cell, ARGOS System

\section{1. 緒言}

漁業活動が影響を与える水棲生物の資源状況などを調べ るために、データロガーを用いた水棲生物の生態研究が 行われている。研究で用いられるデータロガーには、アー カイバルタグとアーカイバルポップアップタグがある ${ }^{1,2)}$ 。 アーカイバルタグは対象生物の体内などに設置して温度や 圧力などを記録するようなデータロガーで、データを回収 するためにはロガーを装着した対象生物を再捕獲すること が必要である。それに対してアーカイバルポップアップタ グはアンカーを用いて対象生物の体外に設置し、時間など の条件で対象生物から切り離されて水面に浮上するような データロガーである。ロガーを装着した対象生物を再捕獲 する必要はないが、浮上したタグを回収するためにアルゴ スシステムを用いて位置を特定できるような機能を持たせ るのが一般的である。

特に金谷らは、アルゴスシステムと方向探知機を用いて 回収するポップアップタグを提案している ${ }^{2)}$ 。方向探知機 を組み合わせることで夕グの回収率が向上する利点があ るが、電池が持続する間にタグを発見する必要がある。ま た、現在市販されているアーカイバルポップアップタグ は、長期の使用に耐えうる設計を前提としており、浮力の 確保や電池の容量の制限などから、照度 - 圧力 - 温度セン
サのみの搭載品がほとんどである。したがって、対象生物 の大まかな位置と周囲の環境を知ることができるだけで、 姿勢や進行方向の変化などの詳細な情報を得ることがで きない。

そこで本研究では、短期間の対象生物の行動追跡をター ゲットとし、太陽電池を搭載したスマートアーカイバル ポップアップタグを開発した。タグには、照度・圧力・温 度センサに加えて 3 軸加速度センサおよび 3 軸角速度セン サを搭載しており、対象生物の遊泳行動を詳細に記録する ことができる。また、搭載したアルゴス送信機が太陽電池 で動作するように設計し、電池切れによる通信の途絶が起 きないようにした。

\section{2. スマートポップアップタグの設計とその仕様}

本研究で開発したスマートポップアップタグを Fig.1に 示す。アンテナを除く本体の長さは $193 \mathrm{~mm}$ で、最も太い 部分の直径は $42 \mathrm{~mm}$ である。また、アルゴス衛星と通信す るためのアンテナの長さは $182 \mathrm{~mm}$ である。本体は $500 \mathrm{~m}$ の水圧に耐えられる設計仕様である。

対象生物の行動を記録するためのセンサとして、3 軸加 速度センサと 3 軸角速度センサを本体の内部に配置してい る。また、周囲の環境を記録するためのセンサとして、圧 力 / 温度センサと照度センサを本体の上面に配置している。

*近畿大学理工学部電気電子工学科（＝ 577-8502 大阪府東大阪市小若江 3-4-1)

Department of Electric and Electronic Engineering, Faculty of Science and Engineering, Kindai University

(3-4-1 Kowakae, Higashiosaka, Osaka, 577-8502 Japan) 


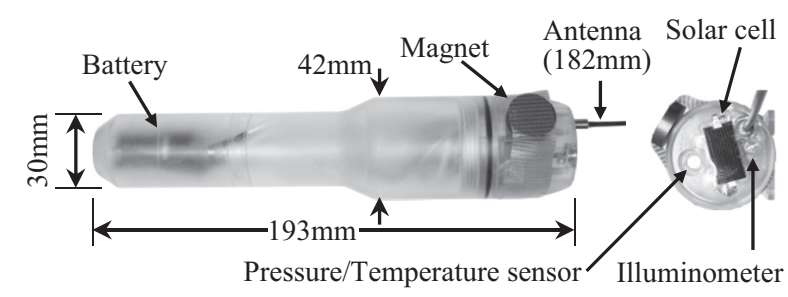

Fig.1 Smart pop-up tag design parts.

Table 1 Specification of the sensors.

\begin{tabular}{|c|c|c|c|}
\hline Type & Model & Range & $\begin{array}{c}\text { Sampling } \\
\text { period }\end{array}$ \\
\hline Accelerometer & LIS3DSH & $-6.0 \sim 6.0 \mathrm{G}$ & $31.25 \mathrm{~ms}$ \\
\hline Angular velocity & L3GD20 & $\begin{array}{c}-2000 \sim 2000 \\
\mathrm{deg} / \mathrm{s}\end{array}$ & $31.25 \mathrm{~ms}$ \\
\hline Pressure & MS5541-30C & $0 \sim 30 \mathrm{bar}$ & $100 \mathrm{~ms}$ \\
\hline Temperature & MS5541-30C & $-40 \sim 85^{\circ} \mathrm{C}$ & $100 \mathrm{~ms}$ \\
\hline Illuminometer & AMS302 & $0 \sim 4095$ & $60 \mathrm{~s}$ \\
\hline
\end{tabular}

これらのセンサで測定したデータは時刻情報とともにマイ クロ SD カードに保存される。特に加速度や角速度を短い 周期で記録することで遊泳行動の詳細な解析を可能にして いる。使用したセンサの仕様を Table 1 に示す。システム は内蔵した一次電池で動作し、約 8 日間にわたってデータ を記録することができる。また、リードスイッチを採用し ており側面の磁石を外すと記録を開始する。

アルゴス衛星への通信は本体上面に配置したアンテナに より行う。通信用の電力を太陽電池で確保することで電池 切れによる通信の途絶が起きないように設計されている。 これによりアルゴス衛星との通信が常に維持されるため夕 グの回収がより確実なものとなる。また、ポップアップタ グが水面に浮上し電力の確保ができると自動的に通信を開 始する機能を有している。アルゴス衛星は水面に浮上した ポップアップタグの位置を特定するためだけに使用してお り記録したデータの送信は行っていない。データの回収は タグそのものを回収することを前提としている。

\section{3. スマートポップアップタグの検証}

開発したポップアップタグの動作確認を模擬環境実験に より検証、評価した。

Fig.2 は夕グを平行移動させた時の 3 軸加速度センサの 時系列データである。縦軸は加速度で横軸は経過時間であ る。加速度センサの Z 軸が概ね鉛直下向きになるようにし て、加速度センサの $Y$ 軸方向に往復運動をさせた。 $Z$ 軸方 向で重力加速が測定できており、Y 軸方向で往復運動に伴 う加速度を測定できていることが分かる。X 軸方向には動

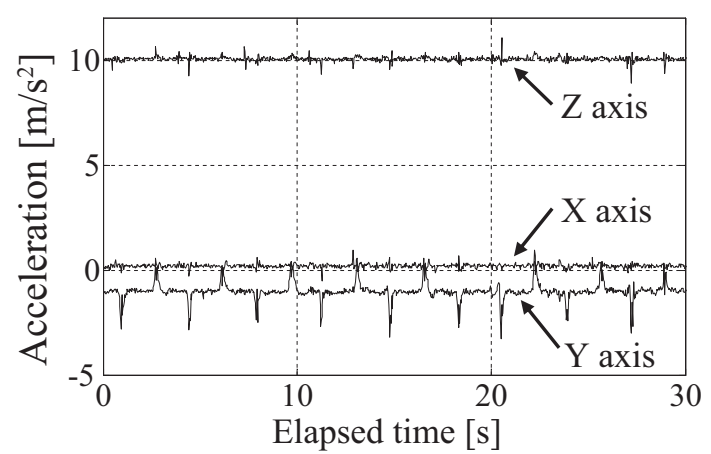

Fig.2 Time dependent of 3-axis Acceleration pretest.

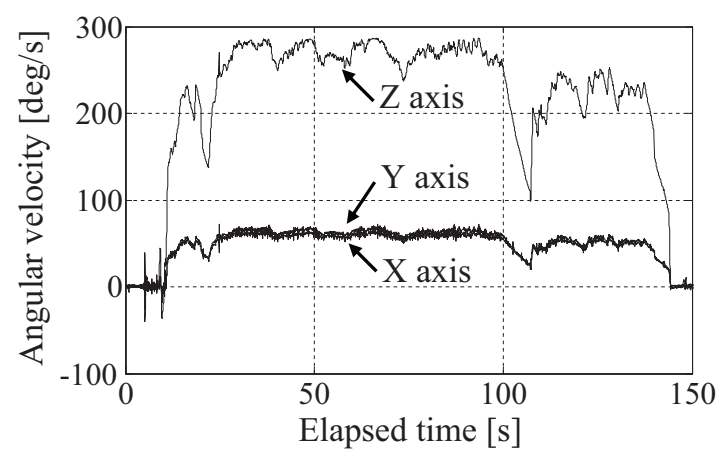

Fig.3 Angular velocity for rotation.

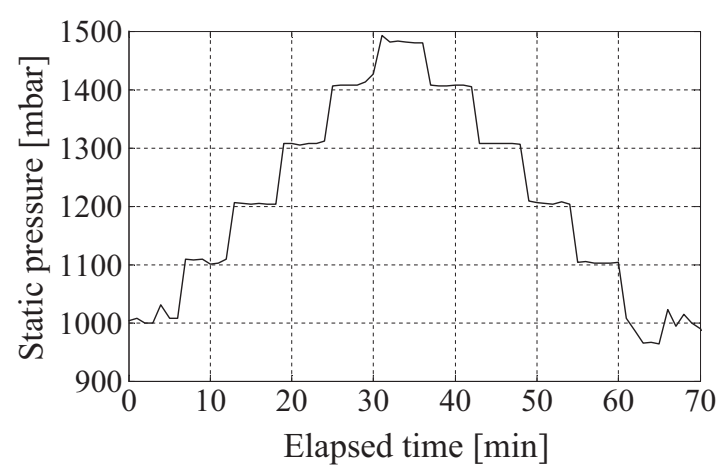

Fig.4 Static pressure into water.

かしていないので、概ね $0 \mathrm{~m} / \mathrm{s}^{2}$ を示している。

Fig.3 は夕グを回転させた時の 3 軸角速度センサの時系列 データである。縦軸は角速度で横軸は経過時間である。角 速度センサの Z 軸が概ね鉛直上向きになるようにして水平 面上で回転させた。 $Z$ 軸周りの角速度が測定できているこ とが分かる。また、X軸および $\mathrm{Y}$ 軸周りの角速度が測定さ れていることから、センサの Z 軸が鉛直方向から少し傾い ていたことが分かる。

Fig.4 は夕グを水中に沈めたときの静圧力の時系列デー 夕である。Fig.4の縦軸は静圧力で横軸は経過時間である。 
タグの水深を 6 分毎に $1 \mathrm{~m}$ ずつ変化させたデータを示す。 図から $1 \mathrm{~m}$ ずつ沈めた時の圧力の変化が測定できているこ とが分かる。

\section{4. 結言}

本研究では、魚類などの水棲生物の行動を記録するアー カイバルポップアップタグを開発した。開発したタグは対 象生物の遊泳行動を詳しく解析できるように短い周期で加 速度および角速度を記録し、対象生物の周囲の環境が分か るように静圧力や温度、照度を記録するように設計した。 また、水面に浮上したタグを見つけられるように、太陽電
池駆動のアルゴス送信機を搭載した。模擬環境検証実験を 通して開発したタグが正常に動作することを確かめた。

今後、水棲生物にタグを装着して実フィールドでの検証 を行う。

\section{参考文献}

1) 張成年:まぐろ·かじき類の系群判別、水産資源管理談話会報、 31(2003)29-38.

2) 金谷道昭ほか：データロガー回収用小型人工衛星ポップアッ プタグの開発、極域科学・宙空圈・気水圈・生物・地学シン ポジウム講演予稿集、2010 (2010) ROMBUNNO.PB22. 